\title{
PENDAMPINGAN TERPADU BERBASIS KAJI TINDAK PEMBELAJARAN BAGI GURU-GURU SAMA DI KABUPATEN KLUNGKUNG DAN KARANGASEM
}

\author{
oleh, \\ I Nyoman Suardana \\ Jurusan Pendidikan Kimia \\ Fakultas Matematika dan Ilmu Pengetahuan Alam \\ Universitas Pendidikan Ganesha
}

\begin{abstract}
ABSTRAK
Mutu pendidikan pada jenjang SMA di Kabupaten Klungkung dan Karangasem masih rendah. Hal ini tercermin dari hasil capaian ujian nasional yang belum optimal, yaitu beberapa kompetensi siswa $<60$. Untuk meningkatan mutu pendidikan ini dilakukan Penerapan Model Pendampingan Terpadu Berbasis Kaji Tindak Pembelajaran. Sasaran progam pengabdian PM-PMP ini meliputi guru-guru mata pelajaran SMA yang di-UNkan, kepala SMA, dan pengawas SMA di Kabupaten Klungkung dan Karangasem. Model pendampingan ini mencakup empat kegiatan pokok, yaitu: (1) diklat pendalaman materi pelajaran, pembelajaran inovatif dan asesmen, lesson study, manajemen sekolah, dan supervisi pendidikan; (2) lesson study di sekolah sampel; (3) evaluasi keefektivan model; dan (4) FGD tindak lanjut pengembangan mutu pendidikan. Hasil penerapan model ini adalah sebagai berikut. Guru, kepala sekolah, dan pengawas memberi respon positif terhadap pelaksanan diklat dan lesson study. Guru-guru dapat melaksanakan lesson study dengan baik. Guru-guru sudah mulai terbuka dengan pembelajaran yang dilakukan. Mereka sangat merasakan manfaat lesson study bahwa pembelajaran yang dirancang dan direfleksikan secara bersama-sama akan lebih baik dibandingkan apabila dilakukan sendiri. Efektivitas pembelajaran, juga ditunjukkan oleh respon positif dari sebagian besar siswa. Melalui lesson study, kepala sekolah dan pengawas dapat mengadakan supervisi langsung terhadap dokumen perangkat pembelajaran dan pembelajaran riil di kelas. Untuk itu, direkomendasikan agar model ini dapat dilanjutkan dan diperluas sasarannya mencakup pendidikan dasar dan menengah.
\end{abstract}

Kata-kata kunci: pendampingan terpadu, kaji tindak pembelajaran, mutu pendidikan

\section{Pendahuluan}

Kabupaten Klungkung terletak pada koordinat $8^{\circ} 39^{\prime}$ LS $115^{\circ} 29^{\prime}$ BT di Provinsi Bali dengan batas-batas wilayah sebagai berikut. Di sebelah Utara Kabupaten Bangli, sebelah Timur Kabupaten Karangasem, sebelah Barat Kabupaten Gianyar, dan sebelah Selatan Samudra India. Ibu kota Kabupaten Klungkung terletak di Semarapura. Luas wilayah Kabupaten Klungkung $315 \mathrm{Km}^{2}$. Kabupaten Karangasem di lain pihak, terletak pada koordinat $8^{\circ} 22^{\prime}$ LS $115^{\circ} 31^{\prime}$ BT di provinsi Bali dengan ibukota Amlapura. Batas- 
batas wilayah Kabupaten Karangasem adalah sebagai berikut. Di sebelah Utara Laut Bali, sebelah Timur Selat Lombok, sebelah Barat Kabupaten Klungkung dan Bangli, dan sebelah Selatan Samudra India. Kabupaten Karangasem mempunyai 8 kecamatan, 3 kelurahan, 75 desa, 52 Lingkungan dan 552 dusun, 185 Desa Adat dan 605 Banjar Adat.

Di Kabupaten Klungkung terdapat 11 SMA yang mencakup 5 SMA Negeri dan 6 SMA Swasta. Sementara itu, di Kabupaten Karangasem terdapat 20 SMA yang terdiri atas 9 SMA Negeri dan 11 SMA Swasta. Berbagai upaya telah dilakukan pemerintah Kabupaten Klungkung dan Karangasem melalui Dinas Pendidikan Pemuda dan Olahraga untuk meningkatkan mutu pendidikan. Hasil wawancara dengan Kabid Dikmen SMA/SMK/MA Kabupaten Klungkung Bapak I Ketut Suadnyana (2011) dinyatakan bahwa peningkatan mutu pendidikan dilakukan melalui beberapa kegiatan, yaitu: workshop Kurikulum Tingkat Satuan Pendidikan (KTSP), pengengembangan kinerja guru melalui PKG, workshop mata pelajaran melalui MGMP, dan workshop evaluasi diri sekolah (EDS) yang diperuntuk bagi kepala-kepala sekolah. Sementara itu, program-program peningkatan mutu pendidikan dan tenaga kependidikan yang dicanangkan Dinas Pendidikan Pemuda dan Olahraga Kabupaten Karangasem meliputi: pelaksanaan setifikasi pendidik, penetapan angka kredit jabatan fungsional gutu dan tenaga teknis, pemilihan guru dan siswa berprestasi, pemilihan calon kepala sekolah, monitoring dan pengawasan (Renstra Dinas Pendidikan Pemuda dan Olahraga Kabupaten Karangasem tahun 2010-2015).

Walaupun berbagai program dan upaya telah dilakukan untuk meningkatkan mutu pendidikan seperti yang telah diuraiakan di atas, mutu pendidikan pada jenjang SMA di Kabupaten Klungkung dan Karangasem masih rendah. Hal ini tercermin dari tingkat ketidaklulusan siswa dan hasil capaian ujian nasional yang masih belum optimal. Hasil penelusuran Kirna et al. (2011) menemukan bahwa hampir setiap tahun ajaran terdapat cukup banyak siswa yang tidak lulus karena capaiannya masih di bawah nilai standar kelulusan. Hasil capaian siswa SMA di Kabupaten Klungkung dan Karangasem dalam mengikuti UN dari tahun ajaran 2007/2008 sampai dengan 2009/2010 ditemukan bahwa pada tahun ajaran 2007/2008 di Kabupaten Klungkung, siswa yang tidak lulus UN diantaranya: dari SMAN 2 Semarapura sebanyak 2 (1,77\%) dari 113 peserta, dari SMAN 1 Banjarangkan sebanyak $6(8,33)$ dari 72 orang peserta UN, dan dari SMA 
PGRI Klungkung yang tidak lulus UN sebanyak 4 (4,35\%) dari 92 orang peserta UN. Seluruh peserta UN yang tidak lulus dari Kabupaten Klungkung tersebut berasal dari kelompok/jurusan IPS. Di Kabupaten Karangasem, siswa yang tidak lulus UN tahun ajaran 2007/2008 adalah dari SMAN 2 Amlapura sebanyak 1 (1,22\%) dari 82 peserta (IPS), dari SMA 1 Amlapura sebanyak 5 (5, 43\%) dari 92 peserta (IPS), dari SMA PGRI 1 Amlapura sebanyak 23 (10,85\%) dari 212 peserta (IPS), dari SMAN 1 Manggis sebanyak $1(2,70 \%)$ dari 37 peserta (IPA), dari SMAN 1 Sidemen $4(5,48 \%)$ dari 73 peserta (IPA) dan dari kelompok/jurusan IPS sebanyak 13 (34,21\%) dari 38 peserta.

Tingkat kelulusan UN tahun ajaran 2007/2008 tersebut, memang jauh berubah dibandingkan dengan UN tahun ajaran 2008/2009, yang mana hanya ada 1 orang siswa yang tidak lulus UN dari seluruh peserta UN di Kabupaten Klungkung dan Karangasem, yaitu dari SMAN 2 Semarapura (kelompok IPS). Kabupaten Klungkung dan Kabupaten Karangasem untuk pelaksanaan UN tahun ajaran 2008/2009 memang mencapai tingkat kelulusan di atas tingkat kelulusan kabupaten/kota lain di Provinsi Bali. Pada tahun ajaran 2009/2010, tingkat ketidaklulusan peserta UN tampaknya meningkat lagi dibandingkan dengan tahun 2008/2009. Dari seluruh siswa yang ikut UN di Kabupaten Klungkung dan Karangasem ada beberapa peserta yang tidak lulus, diantaranya: dari SMA Parisada Amlapura 2 (5,71\%) dari 35 orang peserta, dari SMAN 1 Nusa Penida sebanyak $2(2,63 \%)$ dari 76 peserta, dari SMA Pariwisata Saraswati Klungkung sebanyak $10(12,35 \%)$ dari 81 peserta. Semua peserta yang tidak lulus tersebut berasal dari kelompok IPS.

Selain angka ketidaklulusan siswa yang hampir setiap tahunnya tetap ada dan cenderung fluktuatif, hasil analisis data terhadap hasil UN tahun ajaran 2007/2008, 2008/2009, dan 2009/2010 juga menunjukkan bahwa penguasaan kompetensi dasar mata pelajaran antara mata pelajaran juga menunjukkan perbedaan yang sangat signifikan. Ada mata pelajaran yang nilai UN-nya sangat tinggi, namun nilai mata pelajaran yang lain sangat rendah. Berbagai temuan tersebut menunjukkan bahwa penguasaan kompetensi siswa terhadap mata pelajaran yang di-UN- kan masih kurang maksimal. Artinya, masih ada mata pelajaran yang di-UN-kan yang secara substansi kurang dikuasi oleh siswa. 
Lebih lanjut, hasil analisis terhadap kompetensi siswa SMA melaui penelitian Pemetaan dan Pengembangan Mutu Pendidikan (PPMP) di Kabupaten Klungkung dan Karangasem pada mata pelajaran yang di-UN-kan menunjukkan bahwa penguasaan pembelajaran tergolong baik (Kirna et al., 2011). Hanya beberapa kompetensi yang masih belum mencapai $\mathrm{KKM}=60$. Kecenderungan persentase kompetensi yang belum mencapai $\mathrm{KKM}=60$ di Kabupaten Klungkung maupun Karangasem adalah identik. Pencermatan terhadap jenis kompetensi yang belum mencapai KKM $=60$ untuk masing-masing mata pelajaran juga memperlihatkan kemiripan di Kabupaten Klungkung dan Karangasem. Hanya mata pelajaran Matematika kelompok IPA, Biologi, dan Sosiologi yang menunjukkan perbedaan yang cukup berarti, sementara mata pelajaran yang lain adalah cenderung sama. Beberapa mata pelajaran hanya berbeda karena adanya perbedaan jumlah kompetensi yang belum mencapai $\mathrm{KKM}=60$.

Bebarapa kompetsnsi siswa yang belum mencapai $\mathrm{KKM}=60$ disebabkan oleh beberapa faktor berikut. 1) Silabus dan RPP yang dikembangkan belum mencerminkan karakteristik sekolah dan belum didasarkan analisis materi yang cermat. 2) Kurangnya kemampuan guru dalam mengembangkan perangkat pembelajaran berpusat pada siswa dan memfasilitasi siswa berpikir tingkat tinggi. 3) Pembelajaran lebih dominan berpusat pada guru, kurang kontekstual, kurang memanfaatkan teknologi. 4) Evaluasi pembelajaran lebih dominan pada aspek kognitif tingkat rendah dan belum signifikan mengarah pada penilaian otentik. 5) Penguasaan guru terhadap materi subjek tertentu masih perlu ditingkatkan. 6) Supervisi baru menyentuh aspek administratif.

\section{Motode Pemecahan Masalah}

Berdasarkan permasalahan utama yang diuraikan di atas, model pengembangan mutu pendidikan yang diharapkan dapat mengatasi masalah di atas adalah "Model Peningkatan Kompetensi Guru SMA melalui Pendampingan Terpadu Berbasis Kaji Tindak Pembelajaran di Kabupaten Klungkung dan Karangasem”. Model ini difokuskan pada pendampingan, yaitu suatu kolaboratif dosen (Tim PM-PMP) dengan pihak sekolah (guru dan kepala sekolah) dan pengawas untuk bersama-sama mencapai tujuan. Kegiatan pengabdian PM-PMP berlokasi di Kabupeten Klungkung dan Kabupaten Karangasem Provinsi Bali. Jumlah SMA yang dilibatkan dalam kegiatan PM-PMP di Kabupaten Klungkung dan Karangasem masing-masing tiga SMA. SMA yang 
dilibatkan di Kabupaten Klungkung adalah SMAN 1 Semarapura, SMAN 1 Dawan, dan SMAN 1 Nusa Penida, sedangkan di Kabupaten Karangasem adalah SMAN 1 Amlapura, SMAN 1 Kubu, dan SMAN 1 Sidemen.

Pihak-pihak yang terlibat dalam kegiatan pengabdian PM-PMP di Kabupaten Klungkung dan Kabupaten Karangasem masing-masing 27 guru mata pelajaran SMA yang di-UN-kan, tiga kepala SMA, tiga pengawas SMA, satu orang Kepala Dinas Pendidikan dan Olah Raga, dan lima dosen tim PM-PMP. Dengan demikian, jumlah total pihak yang terlibat dalam kegiatan pengabdian PM-PMP di masing-masing Kabupaten adalah 39 orang. Penerapan Model Peningkatan Kompetensi Guru SMA melalui Pendampingan Terpadu Berbasis Kaji Tindak Pembelajaran di Kabupaten Klungkung dan Karangasem dilakukan dengan tahapan-tahapan: 1) pendidkan dan latihan (diklat), kaji tindak pembelajaran, 3) evealuasi keefektivan model, dan 4) FGD.

Diklat peningkatan kompetensi guru dilakukan dengan memberikan pendalaman materi kepada guru-guru SMA tentang materi subjek, model-model pembelajaran inovatif dan asesmen serta kaji pembelajaran (lesson study). Sementara itu, diklat untuk kepala sekolah dan pengawas dilakukan dengan memberikan pengetahuan tentang model-model pembelajaran inovatif dan asesmen, kaji pembelajaran, manajemen sekolah, dan supervisi pendidikan.Implementasi terhadap pengatahuan dan keterampilan yang diperoleh selama diklat, ditindaklanjuti dengan melaksanakan kaji tindak pembelajaran. Kaji tindak pembelajaran terdidi atas tiga tahapan, yaitu: tahap perencanaan plan), tahap pelaksanaan tindakan (do), dan tahap refleksi (see) (Saito, et al., dalam Santyasa, 2009). Model Peningkatan Kompetensi Guru SMA melalui Pendampingan Terpadu Berbasis Kaji Tindak Pembelajaran di Kabupaten Klungkung dan Karangasem dievaluasi keefektivannya melalui oberservasi pada pelaksanaan diklat dan kaji tindak pembelajaran (lesson study), respon guru, dan respon siswa

Bertolak dari hasil evaluasi keefektivan Model Peningkatan Kompetensi Guru SMA melalui Pendampigan Terpadu Berbasis Kaji Tindak Pembelajaran di Kabupaten Klungkung dan Karangasem, dilakukan Focus Group Discussion (FGD) dengan melibatkan Kepala Dinas Pendidikan Pemuda dan Olahraga di Kabupaten Klungkung dan Karangasem, kepala sekolah, dan tim PM-PMP. Focus Group Discussion (FGD) untuk merumuskan kebijakan tindak lanjut pengembangan mutu pendidikan yang 
berupa model peningkatan kompetensi guru dan supervisi pendidikan yang dapat diterapkan di semua SMA di Kabupaten Klungkung dan Karangasem.

\section{Hasil dan Pembahasan}

Diklat untuk guru-guru, kepala sekolah, dan pengawas SMA di Kabupaten Klungkung dan Karangasem berlangsung dengan baik dan lancar. Semua (100\%) guru SMA di Kabupaten Klungkung dan 98,7\% guru SMA di Kabupaten Karangasem memberikan respon prositif terhadap pelaksanaan diklat. Guru-guru, kepala sekolah, dan pengawas SMA menunjukkan antusiasme tinggi dalam mengikuti acara diklat. Dalam kegiatan diklat, semua peserta dapat menghadiri kegiatan secara penuh waktu dan tekun mengikuti kegiatan dari awal sampai akhir. Hal ini terjadi karena meteri diklat yang diberikan dapat menyentuh kebutuhan mereka. Banyak pertanyaan yang disampaikan oleh peserta diklat berkaitan dengan lesson study, misalnya: 1) apakah lesson study dilaksanakan untuk semua materi pelajaran atau hanya pada topik-topik tertentu? 2) apakah melalui lesson study akan mampu mengurangi tawuran antar pelajar yang lagi marak-maraknya tergadi akhir-akhir ini? 3) guru-guru kita nampaknya belum siap melakukan lesson study karena mereka sangat sulit menerima kritikan, bagaimana pendapat dan pandangan Bapak berkaitan dengan hal tersebut? Pertanyaan-pertanyaan ini menunjukkan adanya keinginan dari guru-guru dalam melaksanakan lesson study sebagai fokus utama dari kegiatan PM-PMP dalam rangka pembinaan profesi guru. Beberapa guru merasa khawatir kalau mereka mendapat kritikan saat bertindak sebagai guru model. Kekhawatiran ini ditanggapi dengan baik oleh nara sumber, yang mana nara sumber menjelaskan bahwa pelaksanaan lesson study adalah merupakan pembelajaran kita, artinya pembelajaran yang dirancang, dilakukan, dan direfleksikan bersama sehingga kegagalan dalam pelaksanaan lesson study adalah kekagalan bersama, bukan hanya kegagalan guru model. Oleh karena itu, guru model tidak perlu khawatir karena yang diamati pada lesson study lebih fokus pada aktivitas siswa.

Dalam pelaksanaan diklat, peserta juga diberi kesempatan dan dilatih membuat rencana pelaksanaan pembelajaran (RPP) yang akan digunakan dalam lesson study. Pada kegiatan ini, guru-guru dari mata pelajaran yang sama (masing-masing terdiri atas tiga orang guru) secara bertim merencanakan pembelajaran dan menyepakati guru model, tempat, dan waktu pelaksanaan lesson study. RPP untuk masing-masing mata 
pelajaran yang telah dibuat, disempurnakan lebih lanjut di sekolah sampel sesuai dengan kesepakatan tim lesson study. Pembuatan RPP ini masing-masing dibimbing oleh tim PM-PMP selaku nara sumber dalam kegiatan pendalaman materi bidang studi.

Lesson study di Kabupaten Klungkung mendapat respon positif dari sebagain besar guru (92,8\%). Sebanyak 30.8\% guru sebelumnya pernah melaksanakan lesson study dan $57.7 \%$ melakukan refleksi pembelajaran. Ini merupakan cerminan bahwa lesson study sudah dirasakan manfaatnya oleh sebagian besar guru. Hasil lesson study untuk masingmasing mata pelajaran diuraikan sebagai berikut. Pelaksanaan lesson study untuk pelajaran Bahasa Indonesia dilakukan di SMAN 1 Dawan. Kegiatan Lesson study diawali dari perencanaan pembelajaran yang dilakukan pada saat diklat dan disempurnakan lebih lanjut di SMAN 1 Dawan. Materi pembelajaran yang di-lesson study-kan adalah Menulis Surat Dinas. Pelaksanaan pembelajaran dilakukan oleh guru model Drs. I Nyoman Nartha dengan guru observer Dra. Ni Nengah Widiani dan Ni Wayan Sumarningsih, S,Pd.

Hasil refleksi guru model menunjukkan bahwa pembelajaran yang dilakukannya kekurangan waktu dan memerlukan cara-cara tertentu untuk lebih dapat memotivasi siswa. Pengalaman berharga yang diperoleh dari pelaksanaan lesson study adalah siswa lebih termotivasi dan aktif dalam pembelajaran dan guru model mendapat pengalaman mengajar diobservasi oleh kolega. Sementara itu, hasil refeksi dari guru observer menyatakan bahwa tujuan pembelajaran sudah tercapai, pelaksanaan pembelajaran sesuai dengan RPP, dan guru sudah berusaha meningkatkan motivasi siswa. Namun demikian, masih ada hal-hal yang dirasakan kurang oleh guru observer, yaitu: interaksi siswa antar kelompok belum maksimal dan penguatan yang diberikan guru belum optimal sehingga siswa masih ragu terhadap pemahamannya. Lebih lanjut, hasil refleksi dari observer lain (kepala sekolah, pengawas, dan dosen) menyatakan bahwa ditemukan beberapa siswa yang tidak terlibat aktif dalam kegiatan kelompok dan siswa masih ragu terhadap pemahamannya.

Efektivitas pembelajaran juga dapat ditunjukkan dari respon siswa. Sebagian besar siswa $(91,3 \%)$ memberikan respon positif terhadap pembelajaran Bahasa Indonesia yang dilakukan oleh guru. Menurut siswa, aspek pembelajaran yang masih perlu diperbaiki meliputi: pembelajaran belum dapat mendorong kemandirian belajar siswa, 
bahan ajar yang tertulis dalam LKS masih sulit dipahami, asesmen dan evaluasi belum dilaksanakan secara transparan.

Pelaksanaan lesson study untuk pelajaran Bahasa Inggris dilakukan di SMAN 1 Dawan. Kegiatan Lesson study diawali dari perencanaan pembelajaran yang dilakukan pada saat diklat dan disempurnakan lebih lanjut di SMAN 1 Dawan. Materi pembelajaran yang direncanakan adalah Text Explanation yang berjudul Tsunami. Selanjutnya, pelaksanaan pembelajaran bahasa Inggris dilakukan oleh guru model I Wayan Lunga, S.Pd dengan guru observer I Nengah Sumartha, S.Pd. Pada saat refleksi, guru model menyampaikan bahwa beliau masih belum tenang dalam menyampaikan materi pembelajaran karena ini merupakan pertama diobservasi oleh kolega. Di samping itu, bapak Wayan Lunga juga menyatakan bahwa evaluasi belum dapat dilakukan karena kekurangan waktu.

Lebih lanjut, hasil refeksi dari guru observer menyatakan bahwa hal-hal positif yang ditemui adalah: tujuan pembelajaran sudah tercapai, pelaksanaan pembelajaran sesuai dengan RPP, dan proses pembelajaran menyenangkan. Sebaliknya, hal-hal yang dirasakan kurang optimal adalah: ada siswa yang masih bingung pada saat kelompok ahli dibentuk dan diskusi kelompok ahli masih belum optimal. Sementara itu, hasil refleksi dari observer lain (kepala sekolah, pengawas, dan dosen) juga hampir sama, yaitu: secara umum siswa sudah aktif, hanya beberapa yang tidak aktif; dalam pelaksanaan pembelajaran dengan menggunakan model kooperatif Jigsaw, perlu disediakan waktu lebih lama pada saat kelompok ahli kembali kekelompoknya. Efektivitas pembelajaran yang dilihat dari respon siswa, yaitu sebagian besar siswa (90\%) memberikan respon positif terhadap pembelajaran Bahasa Inggris yang dilakukan oleh guru. Aspek pembelajaran yang perlu lebih dibenahi meliputi: asesmen dan evaluasi yang dilaksanakan perlu lebih transparan dan instrumen asesmen agar sesuai dengan kompetensi yang dituntut.

Pelaksanaan lesson study untuk pelajaran matematika dilakukan di SMAN 1 Dawan. Kegiatan Lesson study diawali dari perencanaan pembelajaran yang dilakukan pada saat diklat dan disempurnakan lebih lanjut di SMAN 1 Dawan. Materi pembelajaran yang direncanakan Trasformasi Geometri. Selanjutnya, pelaksanaan pembelajaran dilakukan oleh guru model Drs. I Wayan Sukara dengan guru observer 
Agus Soleh, S.Pd., dan Kadek Afi Artami, S.Pd. Pada saat refleksi, guru model menyampaikan bahwa beliau lupa menyampaikan indikator/tujuan pembelajaran di awal pembelajaran, namun beliau akhirnya menyampaikan tujuan pembelajaran pada saat pembelajaran inti berlangsung. Di samping itu, Bapak Sukara juga menyampaikan bahwa dalam proses pembelajaran lebih baik ada sedikit penjelasan materi sebelum siswa diminta mengerjakan LKS secara kelompok. Beliau juga menyatakan bahwa dalam melaksanakan pembelajaran yang diobservasi oleh kolega dan atasan, beliau masih sedikit grogi walaupun sudah lama menjadi guru.

Hasil refeksi dari observer lebih menyoroti aspek negatif yang ditemui dalam pelaksanaan pembelajaran, yaitu: ada beberapa siswa yang masing bingung tentang materi yang dipelajari, jumlah siswa yang terlalu banyak (36 siswa), siswa belum paham menulis notasi/simbol, waktu diskusi kelompok awal waktunya perlu ditingkatkan, dan presentasi sebaiknya ditunjuk secara acak oleh guru. Walalupn respon observer terhadap pelaksanaan pembelajaran matematika lebih banyak menyoroti aspek negatif pembelajaran, namun sebagian besar siswa (90\%) memberikan respon positif terhadap pembelajaran matematika yang dilakukan oleh guru. Menurut siswa, aspek yang perlu lebih ditingkatkan adalah: bahan ajar yang tertulis dalam LKS masih sulit dipahami siswa.

Lesson study mata pelajaran fisika diawali dari penyusunan RPP yang dilakukan pada saat diklat dan disempurnakan lebih lanjut di SMAN 1 Semarapura. Materi fisika yang digunakan untuk lesson study adalah Listrik Bolak-Balik (AC). Pelaksanaan pembelajaran dilakukan oleh Drs. A.A. Ngurah Sucipta sebagai guru model dan I Gusti Nyoman Susanta dan I Gusti Ayu Sri Juniati, S,Pd sebagai guru observer. Bapak A A Ngurah Sucipta sebagai guru menyatakan bahwa lesson study sangat baik diterapkan karena siswa merasa ada yang memperhatikan sehingga siswa yang pada pembelajaran sebelumnya kurang aktif menjadi lebih aktif. Di samping itu, pembelajaran yang dilakukan dalam lesson study lebih dipersiapkan dengan baik bersama tim sehingga pembelajaran dapat berlangsung secara lebih baik.

Sementara itu, komentar observer adalah sebagai berikut. Observer menyatakan bahwa tidak semua siswa berpartisipasi aktif dalam pembelajaran. Dalam pembelajaran yang dilakukan secara berkelompok, ditemukan dua orang siswa dari dua kelompok 
yang berbeda tidak terlibat aktif dalam pembelajaran pada saat siswa lain mengerjakan LKS. Kedua siswa ini mengandalkan temannya untuk mengerjakan LKS. Kedua siswa ini, luput dari pengamatan guru, tetapi dapat diamati oleh observer. Disamping itu, observer juga menyoroti tentang materi pelajaran, yaitu tentang sensitivitas alat ukur. Mereka menyatakan bahwa siswa perlu diberi penjelasan tentang perbedaan hasil pengukuran akibat adanya perbedaan sensitifitas alat ukur yang digunakan. Pembelajaran yang dilakukan guru, juga direfleksikan dari tanggapan siswa terhadap pelaksanaan pembelajaran. Sebagian besar siswa (93,3\%) memberi respon positif terhadap pembelajaran yang dilakukan oleh guru. Aspek pembelajaran yang masih belum optimal adalah berkaitan dengan pembelajaran yang belum mampu mendorong kemandirian belajar siswa.

Lesson study mata pelajaran kimia diawali dari penyusunan RPP yang dilakukan pada saat diklat dan disempurnakan lebih lanjut di SMAN 1 Semarapura. Materi kimia yang digunakan untuk lesson study adalah Rumus Molekul dan Rumus Struktur Turunan Alkana. RPP yang telah dibuat, selanjutnya diterapkan dalam pembelajaran di kelas. Sebagai guru model adalah A.A. Gde Raka Dibiaguna, S.Pd dan guru observer adalah Luh Sumiarsih, S.Pd. dan I Wayan Karyasa, M.Pd. Pada kegiatan refleksi, guru model menyatakan bahwa beliau merasa senang diberi kesempatan untuk melaksanakan pembelajaran yang dirancang bersama tim lesson study. Menurutnya, pembelajaran yang diamati oleh banyak orang membuat anak-anak merasa lebih diperhatikan sehingga anak-anak menjadi lebih bersemangat dan aktif dalam belajar. Di samping itu, guru model menyampaikan bahwa secara umum pembelajaran yang dilakukan sudah berlangsung dengan baik, hanya saja beliau lupa mengecek kehadiran siswa.

Selanjutnya, komentar observer yaitu: pembelajaran yang dilakukan secara umum sudah baik dan siswa sebagian besar sudah berpartisipasi aktif dalam pembelajaran, tetapi ada salah seorang siswa yang memperhatikan kegiatan di luar kelas pada saat temannya menuliskan hasil diskusinya di depat kelas. Di samping itu, ada siswa yang kurang paham dalam merangkai molymod sehingga diberi bimbingan oleh guru; selanjutnya ada satu kelompok mengalami kesulitan dalam merangkai molymod karena lubang molymod agak longgar. Solusi yang ditawarkan untuk mengatasi siswa yang tidak berkonsentrasi pada pembelajaran adalah agar guru model lebih cermat 
memperhatikan semua siswa dan memberi teguran langsung sehingga siswa tetap berkonsentrasi terhadap pelajaran dan tidak mengulangi perbuatan yang tidak baik. Keberhasilan lesson study juga direfeksikan dari respon siswa terhadap pembelajaran. Sebagian besar siswa $(96,7 \%)$ memberi respon positif terhadap pembelajaran yang dilakukan oleh guru. Aspek pembelajaran yang masih perlu diperbaiki adalah bahan ajar yang tertulis dalam LKS agar mudah dipahami siswa.

Lesson study mata pelajaran biologi di Kabupaten Klungkung dilaksanakan di SMAN 1 Semarapura. Materi biologi yang di-lesson study-kan adalah Struktur Anatomi Jantung. Implementasi pembelajaran dilakukan oleh Dra. Komang Susilawati sebagai guru model dan Hari Purnomo, S.Pd. sebagai guru observer. Pembelajaran biologi juga diobservasi oleh kepala SMAN 1 Semarapura, pengawas, dan anggota tim PM-PMP. Pada saat refleksi, guru model menyampaikan bahwa pembelajaran yang beliau lakukan adalah pembelajaran yang seperi biasanya dan tidak hal khusus yang dipersiapkan, tetapi perencanaan pembelajaran dilakukan secara bersama-sama tim lesson study. Menurut guru model, aktivitas siswa tampak lebih aktif ketika ada banyak orang yang mengamati aktivitasnya sehingga pembelajaran sangat kondusif.

Observer mendukung refleksi dari guru model bahwa pembelajaran berlangsung baik dan siswa aktif dalam menemukan jawaban terhadap pertanyaan menggunakan berbagai sumber belajar. Walaupun demikian, observer juga menyampaikan kelemahan dari pembelajaran, yaitu jumlah anggota kelompok tidak berimbang (4 s/d 7 orang per kelompok). Ini menyebabkan tugas yang dibebankan kepada setiap siswa tidak sama.Efekstivitas pelaksanaan pembelajaran biologi yang di-lesson study-kan juga digali dari respon siswa. Sebaian besar siswa $(92,0 \%)$ memberi respon positif terhadap pembelajaran. Aspek pembelajaran yang masih perlu disempurnakan adalah: pembelajaran belum optimal dalam mendorong kemandirian belajar siswa.

Lesson study dilaksanakan di SMAN 1 Nusa Penida. Materi ekonomi yang dilesson study-kan adalah Jurnal Penutup. Tahap awal lesson study adalah menyusun RPP. Implementasi pembelajaran dilakukan oleh Drs. I Dewa Ketut Astawa sebagai guru model dan Drs. I Wayan Sudirka dan I Wayan Widja, S.Pd sebagai guru observer. Pembelajaran ekonomi juga diobservasi oleh kepala SMAN 1 Nusa Penida, pengawas, dan anggota tim PM-PMP. Hasil refleksi guru model menyatakan bahwa ada perasaan 
senang menjadi guru model karena perencanaan pembelajaran dilakukan bersama tim sehingga ada diskusi untuk perbaikan bersama. Beliau juga menyampaikan bahwa kegiatan lesson study sebagai salah satu upaya untuk melakukan perencanaan dan pelaksanaan pembelajaran lebih sempurna (mendekati ideal). Lebih lanjut, observer menyatakan bahwa pembelajaarn sudah berlangsung secara multi arah (siswa-gurubahan ajar). Anak-anak sangat antusias terhadap model yang diterapkan dan kreatif bertanya terhadap hal-hal yang belum dipahami, namun pembelajaran perlu didukung dengan media yang memadai sehingga pembejaran lebih menarik. Efektivitas pembelajaran juga dapat ditunjukkan dari respon siswa. Sebagian besar siswa $(95,3 \%)$ memberi respon positif terhadap pembelajaran. Aspek yang belum optimal adalah: tugas-tugas dalam LKS kurang memberi tantangan belajar bagi siswa.

Pelaksanaan lesson study untuk pelajaran sosilogi dilakukan di SMAN 1 Nusa Penida. Tahap awal lesson study adalah menyusun perencanaan pembelajaran yang dilaksanakan pada saat diklat dan disempurnakan lebih lanjut di SMAN 1 Nusa Penida. Materi sosiologi yang di-lesson study-kan adalah Mobilitas Sosial. Jmplementasi pembelajaran dilakukan oleh Drs. I Nyoman Arjana sebagai guru model dan Drs. Kadek Putrawan, dan Drs. I Nyoman Sunarta sebagai guru observer. Pembelajaran sosiologi juga diobservasi oleh kepala SMAN 1 Nusa Penida, pengawas, dan tim PM-PMP.

Pada saat refleksi, guru model menyampaikan bahwa beliau merasa masing grogi dalam menyampaikan materi pelajaran karena baru pertama pembelajarannya diobservasi oleh kolega dan atasan, namun beliau tetap menaruh harapan jika hal ini terus dicobakan rasa grogi tersebut akan dapat dikurangi. Sementara itu, hasil refleksi dari observer menyatakan bahwa posisi tempat duduk dari siswa pada saat diskusi kelompok perlu diperhatikan sehingga tidak ada siswa yang saling membelakangi temannya. Di sampang itu ditemukan beberapa siswa tidak aktif dalam pembelajaran. Oleh karena itu, guru hendakan dapat melakukan pengaturan tempat duduk sehingga semua siswa saling berhadapan dan lebih cermat mengamati siswa dalam pembelajaran.

Efektivitas pembelajaran juga ditunjukkan dari respon siswa. Sebagian besar siswa $(87,3 \%)$ memberi respon positif terhadap pembelajaran yang dilakukan oleh guru. Aspek pembelajaran yang masih belum optimal adalah: media yang digunakan kurang 
menarik dan kurang dapat membantu siswa untuk memahami materi yang dibelajarkan, serta asesmen dan evaluasi dilaksanakan kurang transparan.

Lesson study mata pelajaran geografi dilaksanakan di SMAN 1 Nusa Penida. Materi geografi yang di-lesson study-kan adalah Jenis-Jenis Sumber Daya Alam. Tahap awal lesson study adalah menyusun perencanaan pembelajaran yang dilaksanakan pada saat diklat dan disempurnakan lebih lanjut di SMAN 1 Nusa Penida. Selanjutnya, implementasi pembelajaran dilakukan oleh I Ketut Wirta, S.Pd., M.Pd. sebagai guru model dan Drs. I Putu Suparta, dan Drs. Ketut Bajra sebagai guru observer. Hasil refelksi pembelajaran oleh guru model menyatakan bahwa beliau sudah melaksanakan pembelajaran sesuai RPP yang disusun bersama tim. Walaupun demikian masih ada beberapa hal perlu diperbaiki, di antaranya: pemanfaatan media dan penerapan asesmen.

Refleksi yang disampaikan guru model, juga didukung oleh observer bahwa guru model sudah menerapkan pembelajaran sesuai indikator/tujuan pembelajaran Walaupun demikian, observer juga menyarankan agar dirancang pembelajaran inovatif yang dapat mendorong siswa lebih aktif dalam pembelajaran. Di samping itu, melalui lesson study dapat ditemukan kelebihan dan kekurang model yang diterapkan. Efektivitas pembelajaran yang direfleksikan dari respon siswa yaitu sebagian besar siswa (94\%) memberi respon positif terhadap pembelajaran. Aspek pembelajaran yang perlu diperbaiki adalah media yang digunakan kurang menarik bagi siswa. Lesson Study di Kabupaten Karangasem mendapat respon positif dari sebagian besar guru (98,3\%). Sebelumnya, hanya $8 \%$ guru sudah pernah melakanakan lesson study, 4\% guru melakukan refleksi pembelajaran dan melatih siswa untuk mengemukakan pendapat secara produktif. Hasil lesson study untuk masing-masing mata pelajaran diuraikan sebagai berikut.

Lesson study mata pelajaran Bahasa Indonesia di lakukan di SMAN 1 Sidemen. Lesson study diawali dengan perencanaan pembelajaran yang dilakukan pada saat diklat dan disempurnakan lebih lanjut di SMAN 1 Sidemen. Materi pembelajaran yang direncanakan adalah Unsur Instrinsik Cerpen. Selanjutnya, pembelajaran dilakukan oleh guru model Drs.Nengah Sumiarta dengan guru observer Dra. Desak Made Sriastini, M.Pd. dan Dewa Ayu Adi Putri, M.Pd. 
Pada saat refleksi, guru model menyampaikan bahwa beliau belum mampu menggunakan alat peraga secara maksimal dan dengan pengalaman yang diperoleh sebagai guru model, beliau dapat terus berlatih sehingga dapat digunakan untuk perbaikan pembelajaran berikutnya. Sementara itu, hasil refeksi observer menyatakan bahwa kerunutan atau tahapan-tahapan dalam penyampaian materi perlu dipertahankan dan materi yang disajikan perlu disesuaikan dengan waktu pembelajaran. Bila ada siswa yang memberikan jawaban benar perlu diberikan penguatan (reward) sehingga siswa menjadi termotivasi dalam menjawab pertanyaan. Di samping itu, disampaikan bahwa perlu dilakukan tindak lanjut (misalnya berupa PR) pada akhir pembejaran sehingga siswa mengetahui apa yang semestinya dilakukan setelah pembelajaran usai.Efektivitas pembelajaran juga dapat ditunjukkan dari respon siswa. Hampir semua siswa $(98,7)$ memberikan respon positif terhadap pembelajaran. Semua aspek pembelajaran mendapat tanggap positif dari siswa.

Lesson study pelajaran Bahasa Inggris dilakukan di SMAN 1 Sidemen. Perencanaan pembelajaran dilakukan pada saat diklat dan disempurnakan lebih lanjut di SMAN 1 Sidemen. Materi pembelajaran yang direncanakan adalah Discussion Text "Modern Technology". Lebih lanjut, pelaksanaan pembelajaran Bahasa Inggris dilakukan oleh guru model I Komang Gede Nesa, S.Pd dengan guru observer I Made Krana, S.Pd., dan Ni Made Sri Martiningsih, S.Pd. Pada saat refleksi, guru model menyampaikan bahwa beliau merasa grogi dalam menyampaikan pembelajaran karena pembelajaran diamati oleh banyak observer. Di samping itu, beliau juga menyampaikan tentang keterbatasan waktu dalam pembelajaran.

Walaupun guru model menyatakan grogi dalam melaksanakan pembelajaran, tetapi observer menyatakan bahaw guru model telah menyampaikan materi pembelajaran dengan baik sehingga siswa tidak mengalami kesulitan belajar. Interaksi antar siswa, dan siswa dengan guru berlangsung baik. Namun, volume suara dari guru model perlu lebih dimaksimalkan sehingga dapat didengar baik oleh siswa. Di samping itu pembentukan kelompok yang besar juga kurang efektif sehingga pengawasan siswa dalam kelompok kurang maksimal. Efektivitas pembelajaran juga dapat ditunjukkan dari respon siswa. Sebagian besar siswa (94\%) memberikan respon positif terhadap 
pembelajaran Bahasa Inggris. Semua aspek pembelajaran mendapat respon positif dari siswa.

Lesson study pelajaran matematika dilakukan di SMAN 1 Amlapura. Lesson study ini diawali dengan perencanaan pembelajaran yang dilakukan pada saat diklat dan disempurnakan lebih lanjut di SMAN 1 Amlapura. Materi pembelajaran yang direncanakan adalah Persamaan Lingkaran. Selanjtnya, pelaksanaan pembelajaran matematika dilakukan oleh guru model Drs. I Wayan Gede dengan guru observer Luh Mahayani Ngurah Putri, S.Pd., dan I Putu Budiasa, S.Pd. Pada saat refleksi, guru model menyampaikan bahwa beliau senang diberi kesempatan sebagai guru model. Pembelajaran yang beliau lakukan sudah mengupayakan semaksimal mungkin sesuai dengan RPP yang dibuat secara bersama-sama dengan tim lesson study. Pelaksanaan pembelajaran dirasakan lebih baik dari pembelajaran sebelum-sebelumnya karena persiapan pembelajaran yang dilakukan secara bertim juga lebih sempurna.

Hasil refeksi dari observer menyatakan bahwa pembelajaran yang dilakukan secara umum sudah baik, tetapi ada sedikit kekurang berkaitan dengan saat pembahasan jawaban siswa, tidak semua siswa diminta untuk menghadap ke depan untuk memperhatikan jawaban yang ditulis oleh temannya di papan tulis. Di samping itu, guru model kurang cermat mengamati siswa sehingga ditemukan siswa yang kurang aktif dalam mengerjakan pekerjaan kelompok; hal ini luput dari pengamatan guru. Efektivitas pembelajaran juga ditunjukkan dari respon siswa. Sebagian besar siswa $(93,3 \%)$ memberikan respon positif terhadap pembelajaran matematika. Menurut siswa, salah satu aspek pembelajaran yang perlu diperbaikai adalah media pembelajaran yang digunakan guru kurang menarik.

Lesson study diawali dari penyusunan RPP yang dilakukan pada saat diklat dan disempurnakan lebih lanjut di SMAN 1 Amlapura. Materi fisika yang digunakan untuk lesson study adalah Dinamika Partikel. Pelaksanaan pembelajaran dilakukan oleh Putu Dwika Putri Dharmadewi, S.Pd., M.Pd.sebagai guru model dan I Wayan Subrata, S.Pd., M.Pd. dan I Wayan Dana, S.Pd., M.Pd sebagai guru observer. Pada saat refleksi, guru model menyampaikan bahwa pembelajaran yang beliau lakukan mengacu kepada RPP yang dibuat bersama tim lesson study. Beliau mencoba pembelajaran inovatif kooperatif tipe Jigsaw II yang sebelumnya belum pernah dicobakan. Dengan demikian, melalui 
lesson study ini beliau dapat belajar dalam menerapkan model inovatif baru sehingga diharapkan dapat meningkatkan kualitas pembelajaran. Beliau menyatakan dengan menerapkan model inovatif ini, tentukan masih ada kekurangan yang dilakukan, tetapi ini sebagai titik awal untuk pembaikan pembelajaran berikutnya.

Hasil refleksi observer menyatakan bahwa secara umum pembelajaran sudah baik, tetapi masih ditemukan beberapa kelemahan, di antaranya: jumlah anggota kelompok yang terlalu banyak (7-8 orang per kelompok) menjadikan pembelajaran kurang efektif. Pembahasan di kelompok asal dilakukan secara konvensional (siswa ramai-ramai menjawab) sehingga kurang memberdayakan siswa. Siswa hanya diajak berpikir tingkat rendah (pilihan ganda), tidak ada pemberdayaan nalar siswa. Efektivitas pembelajaran juga ditunjukkan dari respon siswa, sebagian besar siswa (96,7\%) memberi respon positif terhadap pembelajaran. Aspek pembelajaran yang perlu lebih disempurnakan adalah bahan ajar yang tertulis dalam LKS agar mudah dipahami oleh siswa.

Tim lesson study mata pelajaran kimia diawali dari penyusunan RPP yang dilakukan pada saat diklat dan disempurnakan lebih lanjut di SMAN 1 Semarapura. Materi kimia yang digunakan untuk lesson study adalah Persamaan Reaksi. Selanjutnya, diikuti dengan pelaksanaan pembelajaran. Sebagai guru model adalah Ni Wayan Eka Pratiwi, S.Pd dan guru observer adalah Drs. I Nyman Jiwa. Satu orang guru observer lainnya tidak hadir dalam kegiatan pembelajaran di kelas. Pada saat refleksi, guru model menyampaikan bahwa pembelajaran dengan lesson study dapat meningkatkan berkualitas pembelajaran, siswa menjadi lebih aktif dan sangat antusias mengikuti pembelajaran. Kendala yang dirasakan adalah keterbatasan waktu yang tersedia sehingga pembelajaran yang dilakukan secara lebih cepat.

Sementara itu, komentar dari para observer menyatakan bahwa secara umum pembelajaran yang dilakukan sudah baik, tetapi agak tergesa-gesa dan materi pembelajaran belum dapat diselesaikan secara tuntas. Dalam pembelajaran terutama dalam diskusi kelas, masih ditemukan beberapa siswa yang tidak aktif dalam diskusi, hal ini masih luput dari pengamatan guru. Efektivitas pembelajaran juga ditunjukkan dari respon siswa, sebagian besar siswa (82\%) memberi respon positif terhadap pembelajaran. Beberapa aspek pembelajaran yang masih perlu disempurnakan adalah: media yang digunakan agar lebih menarik, bahan ajar dalam LKS agar dapat lebih 
mudah dipahami, instrumen asesmen agar lebih mudah dipahami dan sesuai dengan kompetensi yang dituntut.

Lesson study mata pelajaran biologi di Kabupaten Karangasem dilaksanakan di SMAN 1 Amlapura. Materi biologi yang di-lesson study-kan adalah Sistem Rangka. Lesson study diawali dari penyusunan RPP pada saat diklat dan disempurnakan lebih lanjut di SMAN 1 Amlapura. Selanjutnya, implementasi pembelajaran dilakukan oleh Drs. I Made Suta sebagai guru model dan I Made Sudana Mertayasa, S.Pd., M.Pd., dan I Nyoman Suarsana, S.Pd sebagai guru observer. Pada saat refleksi, guru model menyampaikan bahwa pembelajaran masih belum optimal karena kurangnya persiapan pada saat melaksanakan pembelajaran, tetapi beliau tetap memandang bahwa lesson study sangat baik dilaksanakan karena pembelajaran direncanakan bersama tim sehingga banyak masukan yang dapat diperoleh untuk perbaikan kualitas pembelajaran.

Hasil refleksi observer menyatakan bahwa secara umum pembelajaran sudah baik, tetapi dalam mengerjakan LKS, anak-anak sampai ke depan mengamati rangka sehingga kurang efektif; tidak semua siswa dapat mempelajari materi yang sama karena tugas setiap anak materinya dibagi-bagi menjadi sub-sub materi. Di samping itu, guru model lebih banyak menjelaskan daripada memfasilitasi siswa belajar. Efektivitas pembelajaran juga ditunjukkan dari respon siswa, sebagian besar siswa $(96,0 \%)$ memberi respon positif terhadap pembelajaran yang dilakukan oleh guru.

Tahap awal lesson study adalah menyusun perencanaan pembelajaran. Materi ekonomi yang di-lesson study-kan adalah Jurnal Penutup. Selanjutnya, implementasi pembelajaran dilakukan oleh Drs. I Made Sujana sebagai guru model dan I Putu Suci Handayani, S.Pd., dan Ni Komang Astriyani Dewi, S.Pd sebagai guru observer. Pembelajaran ekonomi juga diobservasi oleh kepala SMAN 1 Kubu dan anggota tim PM-PMP. Pada saat refleksi, guru model menyampaikan bahwa pembelajaran yang dilakukan belum optimal dapat meningkatkan aktivitas siswa dan siswa lambat dalam proses penjumlahan. Lebih lanjut, observer menyampaikan hasil refleksinya, yaitu: secara umum lesson study berjalan dengan baik, tetapi guru model tidak menyampaikan tujuan pembelajaran, instrumen penilaian dan media tidak disertakan dalam RPP. Aspek positif lesson study adalah proses pembelajaran dapat ditingkatkan kualitasnya. 
Efektivitas pembelajaran juga ditunjukkan dari respon siswa, sebagian besar siswa (94\%) memberi respon positif terhadap pembelajaran yang dilakukan oleh guru. Aspek pembelajaran yang masih perlu dibenahi berkaitan dengan pembelajaran yang dilakukan guru agar dapat mudah dimengerti siswa.

Tahap awal lesson study adalah menyusun perencanaan pembelajaran yang dilaksanakan pada saat diklat dan disempurnakan lebih lanjut di SMAN 1 Kubu. Materi sosiologi yang di-lesson study-kan adalah Peran dan Fungsi Lembaga Sosial. Selanjutnya, implementasi pembelajaran dilakukan oleh Drs. I Gede Nyoman Winata sebagai guru model dan Drs. I Ketut Wika, dan Ni Ketut Suryantini, S.Sos. sebagai guru observer. Pembelajaran sosiologi juga diobservasi oleh kepala SMAN 1 Kubu dan tim PM-PMP. Pada saat refleksi, guru model menyampaikan bahwa diskusi dalam pembelajaran membutuhkan waktu lebih lama dan kreativitas siswa dalam diskusi perlu ditingkatkan agar proses diskusi berlangsung lebih efektif dan efisien. Sementara itu, hasil refleksi dari observer menyatakan bahwa untuk mengatasi keterbatasan waktu dalam diskusi, siswa hanya ditugaskan mencari masalah yang ada pada lembagalembaga sosial. Di samping itu disampaikan bahwa dalam pelaksanaan lesson study, konsentrasi siswa terpecah karena mereka memperhatikan observer. Ini terjadi karena lesson study di kelas tersebut baru pertama kali dilakukan sehingga siswa tidak terbiasa dengan suasana yang baru. Walaupun ada permasalahan dalam lesson study, guru-guru merasa dapat lebih mengembangkan diri untuk meningkatkan kualitas pembelajaran. Efektivitas pembelajaran juga dapat ditunjukkan dari respon siswa. Sebagian besar siswa $(93,3 \%)$ memberi respon positif terhadap pembelajaran yang dilakukan oleh guru. Menurut siswa, media yang digunakan dalam pembelajaran agar lebih menraik sehingga dapat menumbuhkan minat siswa dalam belajar.

Tahap awal lesson study adalah menyusun perencanaan pembelajaran yang dilaksanakan saat diklat dan disempurnakan lebih lanjut di SMAN 1 Kubu. Materi geografi yang di-lesson study-kan adalah Sumber Daya Alam. Selanjutnya, implementasi pembelajaran dilakukan oleh I Nengah Kariasa, S.Pd. sebagai guru model dan Dra. Ni Ketut Suriarini, dan Drs. I Wayan Suwitra Arnyana sebagai guru observer. Pada saat refleksi, guru model menyampaikan bahwa beliau belum maksimal dalam melakukan proses pembelajaran karena banyak kekurangan yang beliau rasakan. 
Sementara itu, refleksi dari observer menyatakan bahwa guru model semestinya melaksanakan pembelajaran sesuai dengan skenario yang terdapat dalam RPP yang telah dibuat bersama tim. Guru model kurang memberikan penguatan terhadap materi pembelajaran sehingga siswa masih belum maksimal dapat memahami meteri tersebut. Di samping itu, guru model belum melengkapi RPP dengan LKS dan belum dapat memotivasi siswa dalam pembelajaran. Komenter dari observer lebih banyak menyoroti kelemahan pembelajaran yang dilakukan guru model. Semestinya, observer lebih banyak mengamati aktivitas siswa sehingga diketahui bagaimana siswa belajar, dan selanjutnya dapat mencarikan solusi berkaitan dengan masalah pembelajaran.Walaupun observer lebih banyak menyoroti kelemahan pembelajaran yang dilakukan oleh guru model, tetapi siswa sebagian besar siswa $(95,3 \%)$ memberi respon positif terhadap pembelajaran yang dilakukan oleh guru.

FGD untuk merumuskan kebijakan tindak lanjut model peningkatan mutu pendidikan dilaksanakan pada tanggal 14 Desember 2012 di Undiksha. Peserta yang diundang dalam FGD adalah kepala SMA dari sekolah sampel, kepala dinas pendidikan dan olah raga Kabupaten Klungkung dan Karangasem, dan kepala dinas pendidikan dan olah raga Provinsi Bali. FGD ini dilakukan bersamaan dengan program pengabdian PMPMP dari kabupaten/kota yang lain. Dalam FGD ini, semua peserta, dalam hal ini perwakilan dinas pendidikan dan oleh raga Provinsi Bali, dinas pendidikan dan oleh raga kabupaten/kota se-Provinsi Bali, kepala SMA dan LPM Undiksha menyatakan komitmen untuk melanjutkan model pendampingan terpadu berbasis kaji tindak pembelajaran untuk peningkatan mutu pendidikan.

\section{Penutup}

Berdasarkan uraian tentang efektivitas pelaksanakan pendampingan terpadu berbasis kaji tindak pembelajaran di Kabupaten Klungkung dan Karangasem dapat disimpulkan bahwa guru-guru, kepala sekolah, dan pengawas SMA Kabupaten Klungkung dan Karangasem menunjukkan antusiasme yang tinggi dan respon postif terhadap pelaksanaan diklat dan lesson study. Guru-guru mata pelajaran yang di-UNkan dapat melaksanakan lesson study dengan baik. Guru-guru sudah mulai terbuka dengan pembelajaran yang dilakukan. Mereka sangat merasakan manfaat lesson study bahwa pembelajaran yang dirancang dan direfleksikan secara bersama-sama akan lebih 
baik dibandingkan apabila dilakukan sendiri. Efektivitas pembelajaran yang dilakukan guru juga mendapat respon positif dari sebagian besar siswa. Dengan lesson study, siswa akan menjadi lebih aktif karena merasa diamati oleh banyak orang. Kepala sekolah dan pengawas juga merasakan tentang betapa bermanfaatnya kehadiran mereka secara riil dalam proses pembelajaran di kelas. Di samping itu, melalui kegiatan lesson study tidak ada lagi rasa sungkan bagi kepala sekolah dan pengawas untuk mengamati pembelajaran yang dilakukan guru di kelas. Dengan demikian, kepala sekolah dan pengawas tidak hanya mensupervisi dokumen perangkat pembelajaran yang dibuat oleh guru, melainkan juga terhadap kegiatan pembelajaran riil di kelas.

Berdasarkan kelebihan dari model yang disebutkan di atas, peningkatan kompetensi guru untuk peningkatan kualitas pembelajaran bermuara pada peningkatan hasil belajar siswa. Untuk itu, direkomendasikan agar model pendamping terpadu berbasis kaji tindak pembelajaran dapat dilanjutkan dan diperluas sasarannya mencakup semua pendidikan dasar dan menengah.

\section{DAFTAR PUSTAKA}

Dinas Pendidikan Pemuda dan Olahraga. (2011). Rencana Strategis (Renstra) Dinas Pendidikan Pemuda dan Olahraga Kabupaten Karangasem. Amlapura.

Kirna, et al., (2011). Profil Penguasaan Kompetensi Dasar Mata Pelajaran yang di UN-kan pada Siswa SMA dan Alternatif Pemecahan Masalah Rendahnya Mutu Pendidikan di Kabupaten Klungkung dan Karangasem Provinsi Bali. Laporan Penetian Undiksha. Tidak Dipublikasikan.

Santyasa, I W. 2009. Implementasi Lesson Study dalam Pembelajaran. Makalah. Disajikan dalam Seminar Implementasi Lesson Study dalam Pembelajaran bagi Guru-Guru TK, Sekolah Dasar, dan Sekolah Menengah Pertama di Kecamatan Nusa Penida, Tanggal 24 Januari 2009. 